УДК 378.146:811.111

UDC 378.146:811.111

DOI: 10.31475/ped.dys.2021.30.05

YULIANA LAVRYSH,

Doctor of Pedagogical Sciences, Associate Professor

(Ukraine, Kyiv, National Technical University of Ukraine "Igor Sikorsky Kyiv Polytechnic Institute",

Peremohy Av., 37)

ЮЛІАНА ЛАВРИШ,

доктор педагогічних наук, доцент (Україна, Київ, Національний технічний університет України "Київський політехнічний університет імені Ігоря Сікорського», Пр. Перемоги, 37)

ORCID: 0000-0001-7713-120X

OKSANA KORBUT, Senior Lecturer

(Ukraine, Kyiv, National Technical University of Ukraine "Igor Sikorsky Kyiv Polytechnic Institute», Peremohy Av., 37)

ОКСАНА КОРБУТ, старший викладач (Украӥна, Київ, Національний технічний університет Украйни «Київський політехнічний університет імені Ігоря Сікорського», Пр. Перемоги, 37)

ORCID: 0000-0001-6671-3925

SVITLANA BUHA,

Lecturer

(Ukraine, Kyiv, National Technical University of Ukraine "Igor Sikorsky Kyiv Polytechnic Institute», Peremohy Av., 37)

СВІТЛАНА БУГА, викладач

(Україна, Київ, Національний технічний університет України "Київський політехнічний університет імені Ігоря Сікорського», Пр. Перемоги, 37)

ORCID: 0000-0001-9609-2867

\title{
Critical Reflection as a Key Component of Personalized Language Learning in Digital Education Environment at University
}

Критична рефлексія як головний компонент індивідуалізованого навчання мови в умовах цифрової освіти в університеті

У статті розглядається проблема фборлування навичок індивідуалізованого навчання іноземних мов в університеті. У ракурсі проблематики постає аналіз дидактичних умов для ефбективного фбормування навичок індивідуалізованого навчання. Основними умовами визначено вміння самооцінювання та саморефблексї, які допомагають студентам визначити власні освітні потреби, пріоритети, сильні та слабкі сторони. У статті автори пропонують власне розуління критичної ребблексії та стратегії ї̈ формування. 3 метою отрилання даних для аналізу авторами було проведено анкетування викладачів інозелних мов університету, педагогічне спостереження занять та аналіз літератури з зазначеної тематики. Використані методи дослідження дали змогу визначити ключові проблеми, що перешкоджають еббективному фбормування влінь критичної ребблексії. Під час спостережень автори виокремили та описали в статті ефбективні інструленти фборлування критичної рефблексії, зокрела ицброві освітні ресурси. Було доведено, що застосування иифррових освітніх ресурсів підвищуе мотивацію студентів до салорефблексії та додає інтерактивності $i$ мультимодальності навчальнолу процесу. Єдність дидактичного та технологічного підходів $\epsilon$ засадничим дидактичним принципол, на основі якого автори пропонують фборлувати навички критичної ребблексії.

Ключові слова: індивідуалізація навчання, критична рефблексіл, салооиінювання, иифровий освітній ресурс, іноземні мови.

The article presents the problem of foreign languages personalized learning skills formation at the university. From the perspective of the issue, authors disclose an analysis of didactic conditions for the effective formation of foreign languages personalized learning skills formation. The main conditions are 
the skills of self-assessment and self-reflection, which help students identify their own educational needs, priorities, strengths and weaknesses. In the article, the authors offer their own understanding of critical reflection and the strategy of its formation. In order to obtain data for the analysis, the authors conducted a survey of foreign language teachers at the university, pedagogical observation of classes and analysis of literature on this topic. The research methods made it possible to identify key challenges that prevent the effective development of critical reflection skills. During the pedagogical observations, the authors identified and described in the article effective tools for the formation of critical reflection, in particular digital educational resources. It has been proven that the use of digital educational resources increases students' motivation for self-reflection and adds interactivity and multimodality to the learning process. The unity of didactic and technological approaches is a fundamental didactic principle, on the basis of which the authors propose to form the skills of critical reflection.

Keywords: personalized learning, critical reflection, self-assessment, digital resources, foreign languages.

Introduction / Вступ. Modernization of the higher education system is associated with intensive technology integration, internalization as well as humanization and requires the search for new tools and technologies to improve quality of training. In the National Doctrine of Education Development of Ukraine in the XXI Century it is noted that the main purpose of the education system is to create educational environment for the development and self-realization of each person capable of lifelong learning. The issue became crucial for the pedagogical process updating in the context of preparation for the future specialists as competent, independent, active and creative individuals.

The focus of changes in the organization of the educational process in the context of digitalization is to increase its didactic effectiveness. It can be achieved primarily through the personalized learning the transformation of the educational process in a set of individual educational routes, that are defined by personal educational needs of students and their individual psychological and pedagogical characteristics. Digital technologies enhance the personalized learning through the transformations of the content, the pace of learning material acquisition, the level of complexity, the way of presenting educational material, the form of educational activities organization, the level of transparency for other participants of the educational process. Personalization of vocational education by means of digital technologies transforms the learning experience into a dynamic personalized background and a set of personalized values and competencies.

Personalized learning is a complex pedagogical phenomenon, and its implementation and evaluation requires the creation of special didactic conditions. The main methods are peer- and selfassessment that are impossible without the skills of critical reflection.

Aim and Tasks / Мета та завдання. The purpose of this study is to assess the extent to which skills of critical reflection contribute to the development of peer- and self- assessment of personalized learning results. According to constructivism learning theory, critical reflection transforms experience into learning, while the cognitive theory considers it as one of the mental processes important for the development of knowledge through the integration of new knowledge by application of such cognitive strategies as analysis, goal setting and self-assessment. The authors of the paper outline the meaning of critical reflection for the development of personalized learning skills; determine the didactic conditions for reflective skills development and suggest digital tools for self-reflection to foster the personalized learning.

Methods / Методи. This study is exploratory and interpretative in nature. The methodological approach taken in this study is a mixed methodology based on theoretical and empirical methods application. The research data is drawn from such main sources as scientific literature interpretation, teachers' surveys and pedagogical observations. The theoretical background was collected from the critical analysis of recent studies on personalized learning and methods of its development. The empirical data was accomplished by the comparison and generalization of pedagogical observations rubrics. The teachers of foreign language at the National Technical University of Ukraine «Igor Sikorsky Kyiv Polytechnic Institute» participated in the study. We observed 28 lessons, conducted by 14 teachers, with the integration of personalized learning methodology and critical reflection tools application. As a basis for the rubric development we adopted Ash and Clayton (2004) model for the reflection assessment. It included the following elements: connection between the personal experience and discussed topics, self-correction of mechanical mistakes, ability to assess relevance and clarity of statements, identification of personal learning needs, use of self-assessment, analysis of assignments results with a follow up strategy for the improvement. In order to figure out the attitude of teachers towards the personalized learning and critical reflection, we designed a survey that included questions:

1.What is the connection between the critical reflection and personalized learning?

2.What tools of critical reflection do you apply? 
3.What are the challenges of critical reflection development?

4.To what extend do personalized learning and critical reflection facilitate the learning of foreign languages?

5.What additional resources and tools do you need to develop critical reflection?

The data obtained from the observations and questionnaire provided us with the evidences and practical experience on key issues on critical reflection for the in-depth analysis.

Results / Результати. There is a large volume of published studies describing the role of critical reflection for the development of personalized learning skills. Critical reflection is considered to be the key factor for a successful transition from dependent to personalized assessment. Thus, Kember et al. (2008) suggest that "critical reflection"also may be the "key» to success in individualized language learning, while Gholami (2016). emphasizes the importance of providing opportunities for students to understand that some results need to be changed, but not through direct instruction from the teacher about the mistake, but through self-analysis and comparison. Revealing the essential features critical reflection, Gorbunova (2013) emphasizes that reflection is the self-awareness of an individual that is aimed at understanding of own thoughts, actions and values which play a unique role in solving internal problems for self-improvement.

Our appeal to Mezirow's concept (2009) is related to his idea that critical reflection is a central element of individual transformation. The implementation of its basic theoretical provisions allowed us to identify three types of objects of reflection: content, process and preconditions. Thus, reflection of content demonstrate our perception and feelings about the content of the chosen activity. Reflection of the process determines the evaluation of the effectiveness of previous mental activity. However, the emergence of critical reflection occurs during the analysis of the preconditions that led to certain actions. We agree that the first element of critical reflection is the analysis of one's own experience. It is due to a critical self-study of views, a person might construct a new meaning of life and learning. Therefore, we believe that critical reflection is the purposeful, conscious perception of personal cognitive dissonance and the analysis of previous experience.

In order to teach students to analyze their own academic performance, identify needs, strengths and weaknesses before making informed decisions, monitor and evaluate progress toward their goals, Kolb and Kolb (2017) propose a learning cycle, which they define as «experience transformation». The authors outline this cycle as the process by which knowledge is created by transforming experience. The researchers identified four stages of the cycle: reflective observation of experience, abstract conceptualization and active experiment, which leads to further concrete experience or new knowledge.

Analyzing the learning cycle Kolb and Kolb (2017) in the context of the personalized language learning, the stage reflexive observation was interpreted as an analysis of the process of performing the previous task and its possible outcome. Thus, when a student begins to learn a new language, he is asked to analyze his own experience and effectiveness in mastering a similar previous language topic. After that, students move on to the stage of abstract conceptualization, which means formulating priorities and goals for studying and developing an action plan to achieve these goals. The last stage is an active experimentation or testing of what they learned to further form a concrete experience in the next work. Hence, there are two key processes of personalized learning development: the process of critical reflection and making conscious decisions about own learning.

The literature analysis reveals that critical reflection is based on conscious decisions about own learning, and is not an intuitive process of cognition. In addition, critical reflection is a cyclical process in which previous experience becomes the content for new knowledge and discoveries.

The analysis of rubrics for critical application assessment demonstrated that $83 \%$ of teachers understand and expose the connection between personal experience and assignments content and discussions. It means that they accept the existing knowledge and consider it as a basis for the acquisition of new knowledge as a result of experience. The majority of teachers $(n=87 \%)$ were able to tell students about strengths and weaknesses in performing tasks and encouraged the application of self-awareness to address challenges in other contexts. Mostly $75 \%$ of teachers used self-assessment and $85 \%$ of teachers used peer-assessment techniques for mistakes correction and lesson outcomes reflection.

The results of observations as well as the survey evidenced that teachers understand the connection between the critical reflection and personalized learning and employ the refection strategies. Among the most useful tools teachers mentioned ePortfolios, one-minute brief reflections through Google-forms, reflective posts or journals in Padlet or Jamboard, audiovisual recordings through Flipgrid, tools for digital narratives, blogs or vlogs, mind-mapping tools for setting goals and priorities. The most common challenges were students' resilience to perform reflective activates (97\% answers); lack of class time to carry out reflective activities ( $84 \%$ answers); complicated analysis of reflective activities results (62\% answers); lack of knowledge how to combine language learning and reflective 
activities ( $45 \%$ answers). All teachers agreed that critical reflection facilitates the language learning and promotes its long life mastering after the university. As necessary additional resources teachers pointed out pedagogical trainings on critical reflection integration, examples of digital tools to make this process more interactive for students and tools for students' motivation.

Discussion / Обговорення. In the process of language learning, it should be noted that at the initial level of language learning, the assessment system does not encourage students to reflect critically or make decisions, but only promotes the development of opportunities and skills of criterion assessment. As students progress in their studies, tasks become less limited in terms of choosing learning strategies and resources to implement and provide more opportunities for individual decision making and creativity. Thus, the use of personalization is regulated by the level of language learning. With this in mind, teachers should develop a reference set of materials, technologies and resources adapted for students' needs and to the level of language competence.

Critical reflection is an indicator of level of autonomy and allows to regulate and manage own initial activity, to influence the system of norms and standards. We define reflection as the ability of an individual to be aware of the results of own learning, to see the limits and possibilities in solving a learning task, to adjust own actions. As a result of reflection, students are aware of successes and mistakes, are able to determin strategies and choose teaching aids, if they do not correspond to the level and content of the task, develop a critical attitude to own capabilities, skills and resources. As a result, when performing the next task, a wider choice of resources and means is used, assumptions, hypotheses are put forward, logical substantiation and implementation of the chosen solution take place. Critical reflection in professional activities has potential development, which under certain conditions allows the individual to achieve a new level of development. Thus, reflection is built around already existing knowledge, skills, abilities that allow to succeed and analyze the causes of failures and difficulties that inhibit the achievement of planned results. Critical reflection grants:

- to record features of learning dynamics concerning expected results, as well as transformative personal changes;

- to transform the positive and negative experiences of the previous learning towards the foundation for further research and knowledge;

- to analyze results and timely adjust further activities.

We would like to recommend teachers to create a learning environment of trust and creativity. The employment of digital resources is beneficial for the development pf critical reflection and increases students' motivation to perform these tasks. There are several digital diary platforms, such as Evernote, OneNote, Sciblink, Stormboard, and Google Keep. With these tools, students can add websites to audio, images and clips, and when they are synchronized on all devices, the teacher can always see it on a virtual disk. As a diary too we suggest using Microsoft OneNote that integrates with Microsoft 365, keeping the record in OneDrive account. Google Keep is another option, although it has slightly fewer options than others, but it is very quick to take text or audio notes. To keep an online diary, we recommend resources such as Penzu, Journalate or Diaro. They let sort records by folders, tag them by keywords, search for records, and synchronize with mobile devices and the web. Since most of us use smartphones with built-in audio and video recording, we often make short recordings or videos as fast as typing a text. We find the blog platforms WordPress, Blogger and LiveJournal interesting to work with. These tools offer ready-made templates for students to create their own online space or publications. As example we suggest the following questions:

- what goal did you achieve and what did you learn?

- what was the most important for you?

- what was the hardest thing for you to do?

- why did you need extra help?

- how confident you feel within the topic we studied? (Confident, quite confident, not sure).

In order to reflect on learning outcomes, we offer to use the resources Kahoot, Socrative or Anketa Everywhere to design questionnaires. Questionnaires might include the set of questions suggested by the DEAL model (Ash, Clayton, 2004): describe, examine and articulate learning.

- Describe: Where and when did the experience take place? What actions did you/others take? What did you expect from the activity?

- Examine: What concepts/ideas are relevant to this experience and how did they transform your perception of the experience?

- Articulate Learning: What did you realize because of the experience and for what reason is it significant? What determinations did you make from the experience and what are the constraints and implications do those conclusions have?

As a reflective group work we propose peer-assessment techniques because they involve the whole group of students and allows to discuss the most urgent and disputable issues for such reflective 
discussions we recommend such tasks:

- to analyze the content of today's lesson;

- to make a short summary of the studied language topic;

- to write or name the words or phrases they learned;

- to name two qualities or unusual properties of a resource that they are found the most useful;

- to ask a question to which they did not find the answer.

Conclusions / Висновки. The aim of the present study was to examine the role of critical reflection for the enhancing the personal learning. The most obvious finding to emerge from this study is that teachers should create a special environment to integrate the critical reflection activities and one of the most beneficial solution is to use digital tools. However, according to the results of the study we identified some key issues for critical reflection that are important in the context our study:

- critical reflection is the process of rethinking own activities to identify educational needs and analyze the reasons of success and failures with the prospect of correcting actions to achieve the goal;

- critical reflection is an important condition for formation competences for autonomous individual foreign language improvement;

- one of the effective means of developing reflexive skills is awareness and transformation of previous learning experience;

- alternative assessment strategies foster the process of autonomous personalized learning by training reflexive skills.

This study has found that generally the skills of individual foreign language improvement is complex of functionally related abilities: critical reflection of learning experience, orientation to personalization, determination of the quality of personal knowledge of a foreign language in accordance with established standards, carrying out self-assessment of learning outcomes, analyze the received results of training and to design the further individual educational activity.

\section{References:}

Horbunova, L. (2013). Teoriia transformatyvnoho navchannia: osvita doroslykh v umovakh «plynnoi suchasnosti» [Theory of Transformative Learning: Education Adults in Terms of "Current Times»]. Philosophy of education, 2 (13), 66-114 [In Ukrainian].

Ash, S. L., \& Clayton, P. H. (2004). The articulated learning: An approach to guided reflection and assessment. Innovative Higher Education, 29 (2), 137-154 [in English].

Gholami, H. (2016). Self-assessment and Language Autonomy. Theory and Practice in Language Studies, 6 (1), 46-51 [in English].

Kember, D., McKay, J., Sinclair, K., Kam, F., \& Wong, Y. (2008). A four-category scheme for coding and assessing the level of reflection in written work. Assessment \& Evaluation in Higher Education, 33 (4), $369-379$ [in English].

Kolb, A., \& Kolb, D. (2017) Experiential Learning Theory as a Guide for Experiential Educators in Higher Education. Experiential Learning \& Teaching in Higher Education, 1(1), 7-44. Retrieved from: https://nsuworks.nova.edu/elthe/vol1/iss1/7 [in English].

Mezirow, J. (2009). Overview of transformative learning theory. In Contemporary theories of learning: Learning theorists in their own words, ed. K. Illeris, 90-105. New York: Routledge [in English].

Perry, L., Stoner, L., Schleser, M., Stoner, R., Wadsworth, D., Page, R., \& Tarrant, M. (2015). Digital media as a reflective tool: creating appropriate spaces for students to become introspective. Journal of Comparative and International Education, 45 (2), 323-330. doi: 10.1080/03057925.2014.993237] [in English].

\section{Список використаних джерел і літератури:}

Горбунова, Л. С. (2013). Теорія трансформативного навчання: освіта дорослих в умовах «плинної сучасності». Філософбія освіти, 2 (13), 66-114 [in Ukrainian].

Ash, S. L., \& Clayton, P. H. (2004). The articulated learning: An approach to guided reflection and assessment. Innovative Higher Education, 29 (2), 137-154 [in English].

Gholami, H. (2016). Self-assessment and Language Autonomy. Theory and Practice in Language Studies, 6 (1), 46-51 [in English].

Kember, D., McKay, J., Sinclair, K., Kam, F., \& Wong, Y. (2008). A four-category scheme for coding and assessing the level of reflection in written work. Assessment \& Evaluation in Higher Education, 33 (4), 369-379 [in English].

Kolb, A., \& Kolb, D. (2017) Experiential Learning Theory as a Guide for Experiential Educators in Higher Education. Experiential Learning \& Teaching in Higher Education, 1(1), 7-44. Retrieved from: https://nsuworks.nova.edu/elthe/vol1/iss1/7 [in English].

Mezirow, J. (2009). Overview of transformative learning theory. In Contemporary theories of learning: Learning theorists in their own words, ed. K. Illeris, 90-105. New York: Routledge [in English].

Perry, L., Stoner, L., Schleser, M., Stoner, R., Wadsworth, D., Page, R., \& Tarrant, M. (2015). Digital media as a reflective tool: creating appropriate spaces for students to become introspective. Journal of Comparative and International Education, 45 (2), 323-330. doi: 10.1080/03057925.2014.993237] [in English]. 
Дата надходження статті: «22» квітня 2021 р.

Стаття прийнята до друку: «28» травня 2021 р.

Лавриш Юліана - завідувач кафедри англійської мови технічного спрямування № 2 Національного технічного університету України «Київський політехнічний університет імені Ігоря Сікорського», доктор педагогічних наук, доцент

Lavrysh Yuliana - Head of the Department of English for Technical Purposes № 2 of National Technical University of Ukraine «Igor Sikorsky Kyiv Polytechnic Institute», Doctor of Pedagogical Sciences, Associate Professor

Корбут Оксана - старший викладач кафедри англійської мови технічного спрямування № 2 Національного технічного університету України «Київський політехнічний університет імені Ігоря Сікорського»

Korbut Oksana - Senior Lecturer of the Department of English for Technical Purposes № 2 of National Technical University of Ukraine «Igor Sikorsky Kyiv Polytechnic Institute», Doctor of Pedagogical Sciences, Associate Professor

Буга Світлана - викладач кафедри англійської мови технічного спрямування № 2 Національного технічного університету України «Київський політехнічний університет імені Ігоря Сікорського»

Buha Svitlana - Lecturer of the Department of English for Technical Purposes № 2 of National Technical University of Ukraine «Igor Sikorsky Kyiv Polytechnic Institute», Doctor of Pedagogical Sciences, Associate Professor

\section{Цитуйте ию статтю як:}

Лавриш, Ю., Корбут, О., \& Буга, С. (2021). Критична рефлексія як головний компонент індивідуалізованого навчання мови в умовах цифрової освіти в університеті. Педагогічний дискурс, 30, 44-49. doi: 10.31475/ped.dys.2021.30.05.
Cite this article as:

Lavrysh, Yu., Korbut, O., \& Buha, S.. (2021) Critical Reflection as a Key Component of Personalized Language Learning in Digital Education Environment at University. Pedagogical Discourse, 30, 44-49. doi: 10.31475/ped.dys.2021.30.05. 